\title{
Physical and Geographical Regionalization and Environmental Management: A Case Study in Poland
}

\author{
Andrzej Macias, Sylwia Bródka, Marta Kubacka*, Witold Piniarski \\ Department of Landscape Ecology, Adam Mickiewicz University, Poland
}

Received: 9 March 2019

Accepted: 16 July 2019

\begin{abstract}
This paper presents certain aspects connected with the use of physical and geographic regionalization at the level of the Wielkopolskie Voivodeship in Poland. The aspects are important from the point of view of landscape management. Regionalization focuses on unique (one-off) features that distinguish particular regions from one another. The selection of criteria as well as the research procedure applied prove the universal nature of the results obtained. Detailed characteristics of particular units allow for comprehensive analysis of environmental conditions in shaping human activity and the implementation thereof into future strategic and programme documents related to spatial and economic planning on regional and local scales.
\end{abstract}

Keywords: physical and geographical regionalization, landscape management, landscape audit, Wielkopolskie Voivodeship

\section{Introduction}

Today, landscape represents a very limited resource so it is, therefore, important to recognize its potential and optimize its usage. The responsibilities involved in land management are becoming more complex [1-4]. Moreover, public awareness of land management and sustainability issues is growing in many sectors, including spatial planning, and is placing greater expectations on managers to balance competing values [5-7].

Following the birth of the European Landscape Convention (ELC) and its ratification by other

*e-mail: marta.kubacka@amu.edu.pl countries, we have witnessed the development of landscape protection laws as well as the related research and management tools [8-9]. Furthermore, there is still a need for a common and geo-referenced landscape classification system in Europe [10].

The aim of regionalization [11] is to aggregate a large number of geographical areal units into a much smaller number of spatially contiguous regions that group units with similar features. The goal of regionalization is to simplify and/or change spatial representation of data into something that is more meaningful and easier to analyze. Regionalization focuses on unique (one-off) features, distinguishing particular regions from one another. It has been applied to many diverse fields, including demography [12], geomorphology [13], hydrology [14], biogeography [15] and ecology [16]. Additionally, analyzing landscape units and 
their characteristics is essential for understanding the interactions between landscape assessment and land use policy [17]. Regional land cover classification and landscape mapping are effective approaches for characterizing natural resources and landscape ecology [18]. Land cover as the composition and characteristic of land surface elements is the key environmental information and is essential for resource management and policy purposes [19].

The issue of physical and geographical regionalization was initiated in Poland by Nałkowski and Lencewicz in the 19th century, and it was then developed by Kondracki [20-22]. The division proposed by Kondracki [22] refers to the classification of physical and geographical regions of the world in the decimal system. It was performed with use of the deductive method of leading factors [23]. The study was subject to subsequent modifications which were mainly related to the course of the unit boundaries, appurtenance to particular units and indexation in the decimal system [24].

A significant turn in the approach to divisions and classification of landscapes in Poland was driven by the changes that occurred in domestic legislation as a result of the implementation of certain provisions into the ELC. The act of 24 April 2015 amending certain acts in relation to strengthening landscape protection instruments and a draft regulation of the Council of Ministers on the preparation of landscape audits of 16 February 2018, connected with the aforementioned act, assume that the typology and identification of landscapes in a scale of the voivodeship should be based on detailed analysis of the types of topography and land coverage structure within the area of physical and geographical mesoregions. Simultaneously, the ordinance provides for the necessity to determine lower rank landscapes (e.g., physical and geographical microregions) that constitute the basic landscape division enabling precise recognition of the landscape variability within the framework of its particular groups, types and subtypes. Another very important task identified in this document is mapping the transformations that take place in the landscape and determining the forces causing them [25-26].

Therefore, the main goal of the study was to perform physical and geographical microregionalization of the Wielkopolskie voivodeship with the consideration of the possibility to apply it in landscape audit, aimed at identifying priority landscapes. They are understood as areas of particular value due to natural and cultural elements as well as landscape physiognomic values [2728]. Detailed characteristics of particular units included in information sheets and in a numerical database enables comprehensive analysis of the meaning of environmental conditions in landscape protection and landscaping. For this reason, the application of the study is of great importance and, therefore, the possibility of its application in environmental management on a regional level should be emphasized.

Wielkopolskie Voivodeship was chosen as a case study (Fig. 1) to conduct regionalization. This is one of Poland's biggest regions/voivodeships $\left(29,826.5 \mathrm{~km}^{2}\right)$. It is located in central and western Poland. Its characteristic features include the geomorphological conditions that emerged as a result of the presence of the Scandinavian continental glacier. The northern part of the voivodeship is characterized by typical young glacial landscape with high topography dynamics, an abundance of concave forms and the presence of lakes. In addition, a clear band pattern of relief resulting from successive recession of the continental glacier in the glaciation period is a typical feature of the area with young glacial relief. On the other hand, the southern part of the voivodeship is characterized by old glacial relief created during older Pleistocene glaciations. This relief is only slightly varied, dominated by flatlands and mild elevations. It is characterized by the absence of land subsidence and

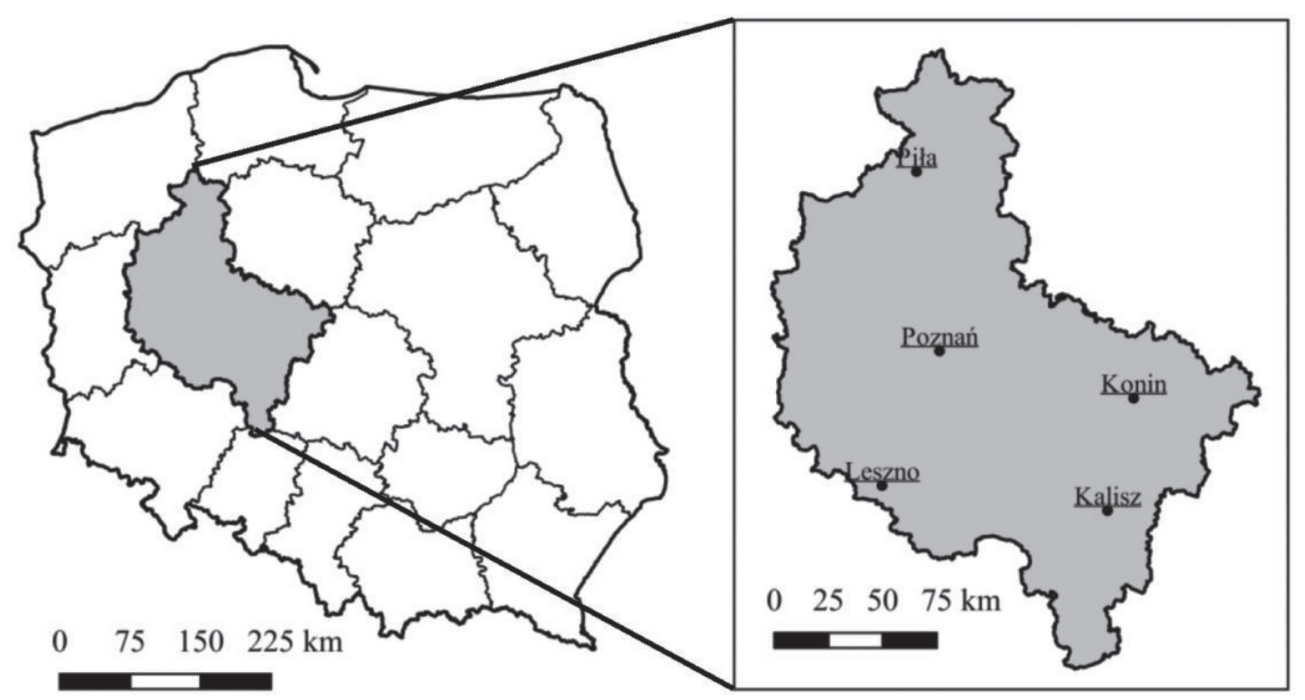

Fig. 1. The location of the research area - Wielkopolskie voivodeship and the most important cities. 
accompanying lakes. The variation of geomorphological conditions in the research area has an impact on land coverage and use as well as the proposed physical and geographical division.

\section{Material and Methods}

In order to maintain the comprehensive nature of the regionalization carried out, the study includes a possibly complete set of features allowing for the analysis of spatial variability of environmental conditions in the scale of the voivodeship. It was assumed that the proposed set of criteria should meet the condition that the properties of the natural environment should be analyzed on an increasing level of detail on lower levels of regionalization. This in turn determined the level of detail of the source data used, most of which corresponded to the 1:50 000 scale. A comprehensive approach was realized by also taking into account biotic (vegetation) elements in the procedure, although they were treated as secondary to abiotic environmental conditions (Table 1).

The source materials gathered have been prepared in a uniform format of vector data (shapefile). All analyses as well as final divisions of microregions have been made in GIS software (QGIS 2.18.9, GRASS 7.2.1 and ArcMap 10.5). An independently elaborated, complex and multi-stage research procedure has been used in the regional unit delimitation process (Fig. 2). The microregions were designated by means of overlaying thematic layers and analyzing the convergence of borders of individual delimited areas. The analysis was the basis for determining border significance and its influence on the possibility to delimit separate regional units.

The research procedure started with the calculation, in the GRASS software, of two-sided buffers of a constant width of $50 \mathrm{~m}(2 \times 25 \mathrm{~m})$, along the route of divisions for each of the environmental components used in the analysis as well as their sum in order to obtain a single vector facility (Table 1). The next step consisted in the multiplication of all previously calculated buffers as a basis for determining their inflections (Fig. 2). There are 6 different data layers corresponding to every component of the natural environment that was selected as a single criterion of the multi-criteria analysis. Multiplying buffers of each of them by each other gives a maximum of 15 unique overlaying variants. Stage 3 was connected with the elaboration of a regular vector grid. One of the initial assumptions was the study accuracy of $50 \mathrm{~m}$ and the determination of the size and shape of basic test fields as squares with an area equal to $2500 \mathrm{~m}^{2}$. The reach of the designated square grid comprised the area of Wielkopolskie Voivodeship. Then, sampling of each of 15 overlaying layers in the elaborated square grid was performed in ArcMap 10.5 software. Next, in a separate vector layer it was calculated how many out of a possible layer multiplications overlay each other in each square. The next stage of tests consisted in the preparation of a boundary density map in the QGIS programme, where the map of the density of intersections of the analyzed boundary buffers was created based on a layer concerning the count of overlaying (Fig. 3). Stage 4 comprised modelling of the route of physical and geographic microregion boundaries by means of the selection of only those objects from the square grid characterized by the biggest number of overlayings, maintaining route continuity. The selection was made by leading lines along the routes of the most certain boundaries (a high number of overlayings). Initially, the lines were led independently (the freehand method) and then the route was made more precise by dragging successive segments of the lines leading directly to the square tips (dragging to tips function, line leading in QGIS).

The next stage of the analysis was connected with the division of areas identified with microregions (Fig. 2). All squares at the route of previously determined overlaying lines constituted areas used for unequivocal designation of the microregion range.

Table 1. Scope of data used in physical and geographic regionalization of Wielkopolskie Voivodeship.

\begin{tabular}{|c|c|c|}
\hline Name of layer & Data details & Source \\
\hline $\begin{array}{c}\text { Geological structure - kind of subsurface } \\
\text { formations }\end{array}$ & 1:50000 & $\begin{array}{l}\text { Detailed Geological Map of Poland } \\
\text { Polish Geological Institute - National Research Institute }\end{array}$ \\
\hline Genetic relief types & $1: 50000$ & $\begin{array}{l}\text { Geomorpholofical map of Wielkopolska and Kujawy Lowland } \\
\text { (ed. Krygowski, 2007) and geomorphological drafts }\end{array}$ \\
\hline Downslope classes & $\begin{array}{l}\text { Resolution } \\
\quad 50 \mathrm{~m}\end{array}$ & $\begin{array}{c}\text { Numerical Land Model - Head Office of Land Surveying and } \\
\text { Cartography }\end{array}$ \\
\hline Soil genetic types & $1: 100000$ & $\begin{array}{l}\text { Soil and agricultural map of the Wielkopolskie Province } \\
\text { - the Institute of Soil Science and Plant Cultivation in Pulawy }\end{array}$ \\
\hline $\begin{array}{l}\text { Groundwaters - depth of deposition of } \\
1 \text { groundwater level }\end{array}$ & $1: 50000$ & Hydrographic map of Poland \\
\hline Types of potential vegetation community & $1: 300000$ & Map of potential vegetation (Matuszkiewicz, 2008) \\
\hline
\end{tabular}

Source: Own works (2019) 


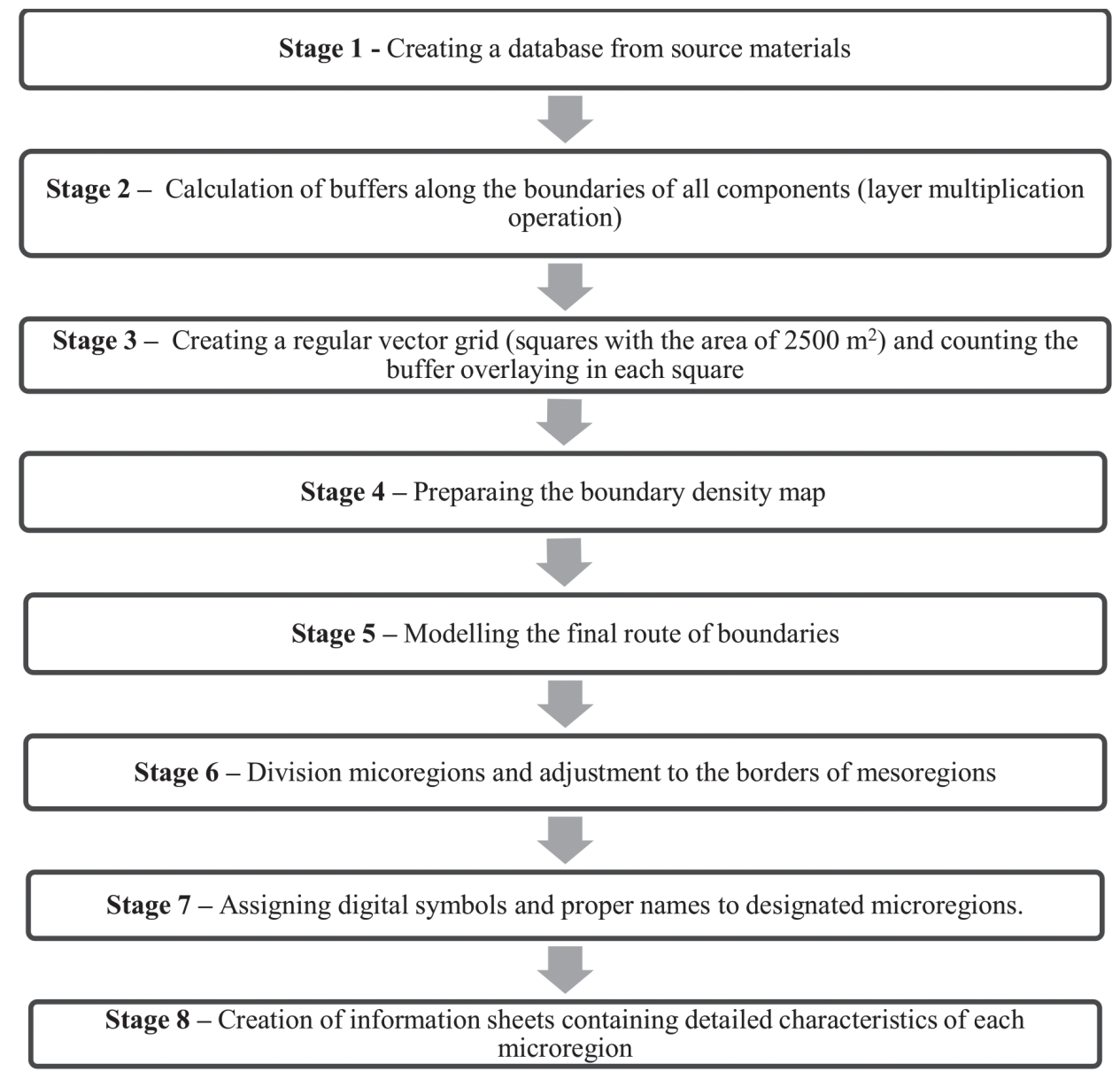

Fig. 2. Stages of research proceedings at delimitation of physical and geographic microregions of the Wielkopolskie voivodeship.

Surfaces of all those squares were added to one another and neighboring objects were merged. Then, middle lines were designated for such areas and in the places of occurring discontinuities, the boundaries were designated with the use of the expert method. The attribute database containing the characteristics of the main features of each unit was elaborated for spatial units created this way. Stage 7 comprised assigning
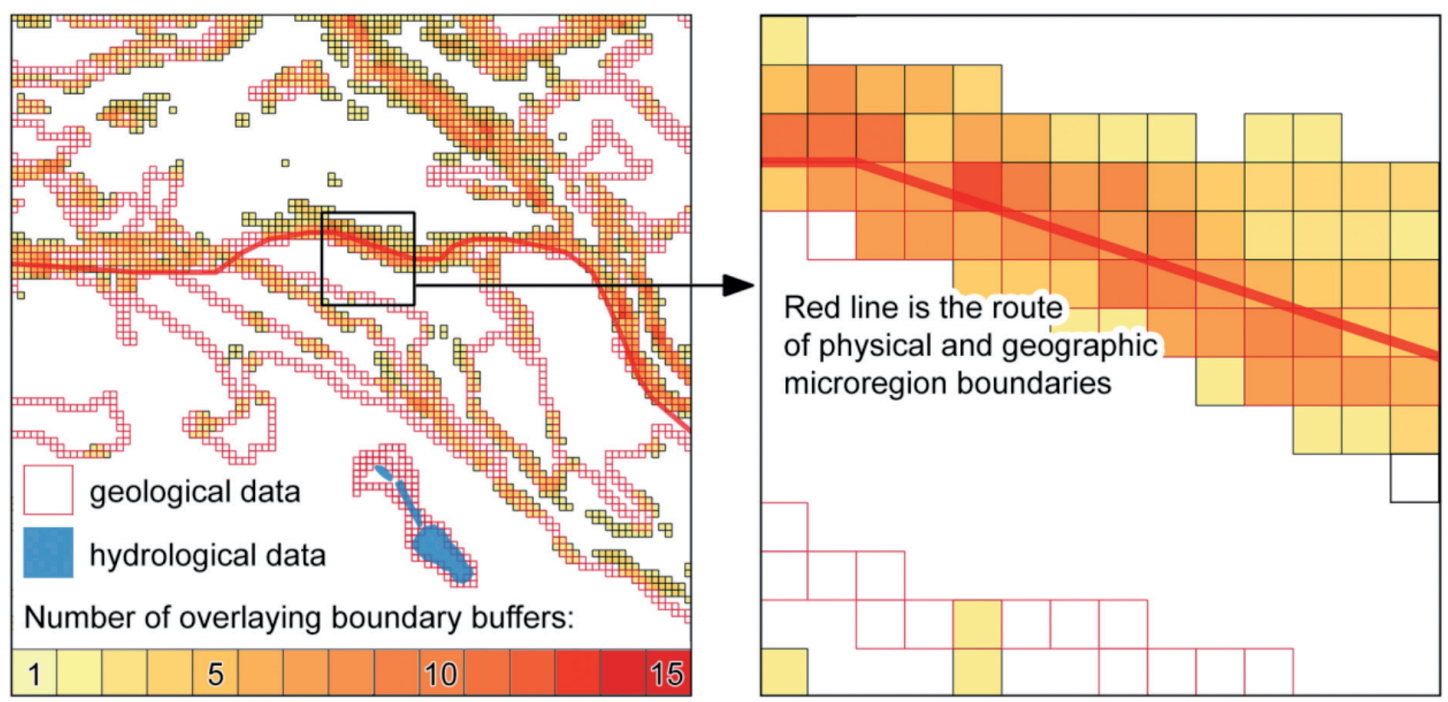

Fig. 3. Visualization of the buffer intersection overlaying at the scale of 1:50 000 against the background of geological and hydrological data and the zoom thereof (the frame on the right hand side). 


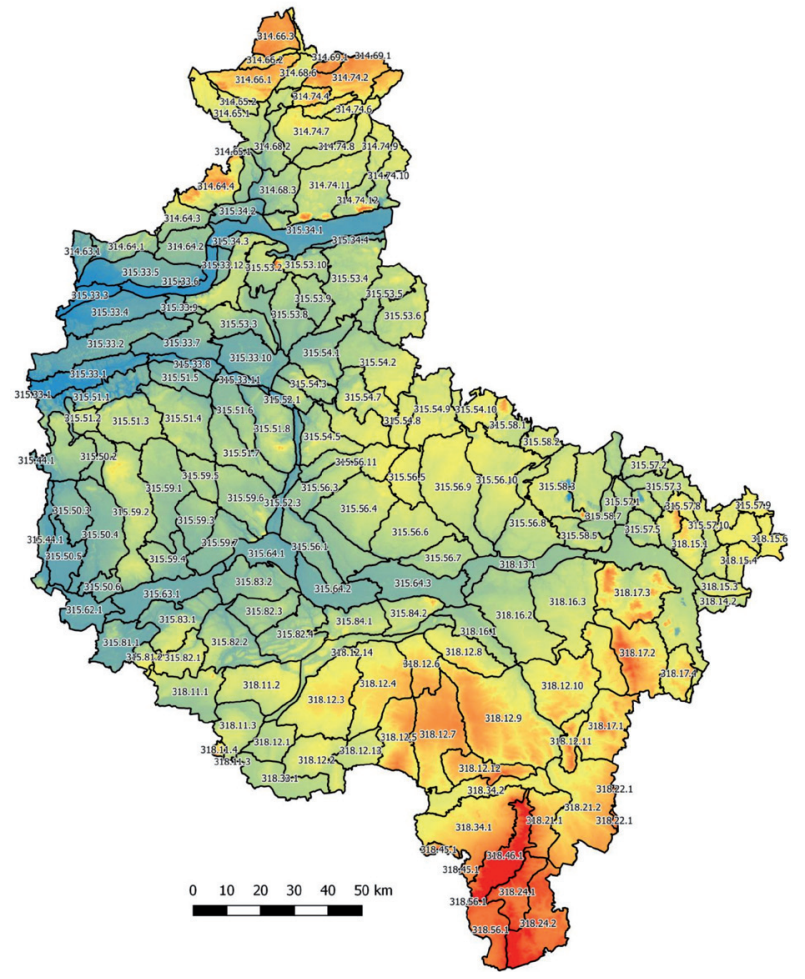

Fig. 4. Division of the Wielkopolskie voivodeship into physical and geographic micro regions. digital symbols and proper names to physical and geographic microregions in accordance with the adopted classification system for physical and geographic regions as per Kondracki [22], and with the consideration of the location of all separated units within the framework of the updated division of the area of Poland into physical and geographic mesoregions. The last element of the analysis consisted of the elaboration of the information sheet for each physical and geographic microregion. The sheet contained quantitative and descriptive data arranged in thematic order.

\section{Results and Discussion}

The most important effect of the research carried out is the physical and geographic regionalization of Wielkopolskie Voivodeship, which is presented in the microregion map prepared in the form of a vector map with the database containing descriptions of all attached units (Fig. 4). As a result of the research procedure, 181 physical and geographic microregions located within the boundaries of 42 mesoregions were delimited (see Appendices, Table 2). High fragmentation of units and their substantial longitudinal range are characteristic of the northern and eastern parts. Such a microregion

Table 2. Physical and geographic microregions of the Wielkopolskie voivodeship

\begin{tabular}{|c|c|}
\hline Mesoregion & Microregions \\
\hline Drawsko Plain (314.63) & 1 unit: Przesieki Sandur (314.63.1) \\
\hline Wałcz Lakeland (314.64) & $\begin{array}{c}4 \text { units: Człopa Hillocks (314.64.1), Trzcianka Plain (314.64.2), Trzcianka Sandur } \\
\text { (314.64.3), Róża Hillocks (314.64.4) }\end{array}$ \\
\hline Wałcz Plain (314.65) & 2 units: Nadarzyce Sandur (314.65.1), Budy Sandur (314.65.2) \\
\hline Szczecinek Lakeland (314.66) & 3 units: Jastrowie Hillocks (314.66.1), Okonek Plain (314.66.2), Lotyń Heights (314.66.3) \\
\hline Gwda River Valley (314.68) & $\begin{array}{l}7 \text { units: Kuźnica Basin (314.68.1), Lower Gwda River Valley (314.68.2), Piła Lakeland } \\
\text { (314.68.3), Kaczory Plain (314.68.4), Jastrowie Basin (314.68.5), Middle Gwda River Valley } \\
\text { - Podgaje Section (314.68.6), Middle Gwda River Valley - Lędyczek Section (314.68.7) }\end{array}$ \\
\hline Northern Krajna Lakeland (314.69) & 1 unit: Człuchów Laleland (314.69.1) \\
\hline Southern Krajna Lakeland (314.74) & $\begin{array}{c}12 \text { units: Kiełpin Heights (314.74.1), Lipka Heights (314.74.2), Lutowo Heights (314.74.3), } \\
\text { Górzna Heights (314.74.4), Zakrzewo Sandur (314.74.5), Złotów Sandur (314.74.6), Krajen- } \\
\text { ka Heights (314.74.7), Śmiardów Plain (314.74.8), Łobżenica Lakeland (314.74.9), Eastern } \\
\text { Wyrzysk Heights (314.74.10), Wysoka Hillocks (314.74.11), Western Wyrzysk Heights } \\
\text { (314.74.12) }\end{array}$ \\
\hline Gorzów Basin (315.33) & $\begin{array}{l}12 \text { units: Międzychód-Sieraków Basin (315.33.1), Noteć Dunes (315.33.2), Krzyż Basin } \\
\text { (315.33.3), Drawsko Plain (315.33.4), Wieleń Plain (315.33.5), Lower Noteć River Valley } \\
\text { (315.33.6), Klempicz Plain (315.33.7), Middle Warta River Valley - Wronki Obrzycko Sec- } \\
\text { tion (315.33.8), Lubasz Plain (315.33.9), Oborniki Basin (315.33.10), Middle Warta River } \\
\text { Valley - Oborniki Section (315.33.11), Romanowo Plain (315.33.12) }\end{array}$ \\
\hline Middle Noteć River Valley (315.34) & $\begin{array}{c}4 \text { units: Middle Noteć River Valley - Chodzież-Ujście Section (315.34.1), Southern Piła } \\
\text { Plain (315.34.2), Ujście Plain (315.34.3), Szamocin Plain (315.34.4) }\end{array}$ \\
\hline Zbąszynek Basin (315.44) & Bruzda Zbąszyńska (315.44.1) \\
\hline Nowy Tomyśl Plain (315.50) & $\begin{array}{l}6 \text { units: Łowyń Sandur (315.50.1), Lwówek Plain (315.50.2), Zbąszyń Plain (315.50.3), } \\
\text { Nowy Tomyśl Sandur (315.50.4), Western Wolsztyn Plain (315.50.5), Eastern Wolsztyn } \\
\text { Plain (315.50.6) }\end{array}$ \\
\hline
\end{tabular}


Table 2. Continued.

\begin{tabular}{|c|c|}
\hline Poznań Lakeland (315.51) & $\begin{array}{c}8 \text { units: Sieraków Lakeland (315.51.1), Kwilcz Hillocks (315.51.2), Pniewy Hillocks } \\
\text { (315.51.3), Western Szamotuły Heights (315.51.4), Northern Szamotuły Plain (315.51.5), } \\
\text { Eastern Szamotuły Heights (315.51.6), Western Poznań Plain (315.51.7), Morasko Hillocks } \\
\text { (315.51.8) }\end{array}$ \\
\hline $\begin{array}{l}\text { Poznań Gap of the Warta River } \\
\qquad(315.52)\end{array}$ & $\begin{array}{c}3 \text { units: Poznań Gap of the Warta River - Oborniki Section (315.52.1), Poznań Gap of the } \\
\text { Warta River - Bolechowo Section (315.52.2), Poznań Gap of the Warta River - Puszc- } \\
\text { zykowo Section (315.52.3) }\end{array}$ \\
\hline Chodzieskie Lakeland (315.53) & $\begin{array}{c}10 \text { units: Czarnków Hillocks (315.53.1), Chodzież Plain (315.53.2), Połajewo Plain } \\
\text { (315.53.3), Gołańcz Lakeland (315.53.4), Wągrowiec Lakeland (315.53.5), Damasławek He- } \\
\text { ights (315.53.6), Flinta River Valley (315.53.7), Gościejewo Plain (315.53.8), Budzyń San- } \\
\text { dur (315.53.9), Chodzież Hillocks (315.53.10) }\end{array}$ \\
\hline Gniezno Lakeland (315.54) & $\begin{array}{c}10 \text { units: Rogoźno Lakeland (315.54.1), Wągrowiec Heights (315.54.2), Goślina Heights } \\
\text { (315.54.3), Eastern Oborniki Heights (315.54.4), Poznań Hillocks (315.54.5), Lednogóra } \\
\text { Heights (315.54.6), Skoki Lakeland (315.54.7), Lednica Heights (315.54.8), Gniezno } \\
\text { Heights (315.54.9), Gniezno Hillocks (315.54.10) }\end{array}$ \\
\hline Września Plain (315.56) & $\begin{array}{l}11 \text { units: Rogalin Plain (315.56.1), Kórnik Plain (315.56.2), Swarzędz Plain (315.56.3), } \\
\text { Środa Heights (315.56.4), Nekla-Czerniejewo Sandur (315.56.5), Western Września Plain } \\
\text { (315.56.6), Pyzdry-Miłosław Heights (315.56.7), Golina-Powidz Plain (315.56.8), Eastern } \\
\text { Września Heights (315.56.9), Słupca Sandur (315.56.10), Pobiedziska Heights (315.56.11) }\end{array}$ \\
\hline Kuyavian Lakeland (315.57) & $\begin{array}{c}10 \text { units: Licheń Sandur (315.57.1), Wierzbinek Hillocks (315.57.2), Sompolno Heights } \\
\text { (315.57.3), Lubstów Heights (315.57.4), Kramsk Hillocks (315.57.5), Przedecz Lakeland } \\
\text { (315.57.6), Osiek Hillocks (315.57.7), Babiak Heights (315.57.8), Chodecz Plain (315.57.9), } \\
\text { Brdów Plain (315.57.10) }\end{array}$ \\
\hline Żnin-Mogilno Lakeland (315.58) & $\begin{array}{c}7 \text { units: Mogilno Lakeland (315.58.1), Orchowo Heights (315.58.2), Ostrowite Heights } \\
\text { (315.58.3), Gopło Lake Gutter (315.58.4), Northern Konin Heights (315.58.5), Kleczew } \\
\text { Heights (315.58.6), Slesin Lakeland (315.58.7) }\end{array}$ \\
\hline Grodzisk Heights (315.59) & $\begin{array}{c}7 \text { units: Grodzisk-Opalenica Plain (315.59.1), Lwówek-Rakoniewice Ridge (315.59.2), Buk } \\
\text { Plain (315.59.3), Grodzisk-Wielichowo Heights (315.59.4), Buk Hillocks (315.59.5), Mosina } \\
\text { Hillocks (315.59.6), Stęszew Heights (315.59.7) }\end{array}$ \\
\hline Kargowa Basin (315.62) & 1 unit: Eastern Kargowa Basin (315.62.1) \\
\hline Middle Obra River Valley (315.63) & 1 unit: Middle Obra River Valley (315.63.1) \\
\hline Śrem Basin (315.64) & $\begin{array}{l}3 \text { units: Mosina Basin (315.64.1), Śrem-Solec Basin (315.64.2), Pyzdry-Zaniemyśl Basin } \\
\text { (315.64.3) }\end{array}$ \\
\hline Sława Lakeland (315.81) & 2 units: Przemęt Lakeland (315.81.1), Włoszakowice Hillocks (315.81.2) \\
\hline Krzywiń Lakeland (315.82) & $\begin{array}{l}4 \text { units: Krzycko Heights (315.82.1), Western Krzywiń Lakeland (315.82.2), Racot Heights } \\
\text { (315.82.3), Dolsk Lakeland (315.82.4) }\end{array}$ \\
\hline Kościan Plain (315.83) & 2 units: Śmigiel Heights (315.83.1), Kościan-Czempiń Plain (315.83.2) \\
\hline Żerków Heights (315.84) & 2 units: Książ Hillocks (315.84.1), Żerków Elevation (315.84.2) \\
\hline Leszno Heights (318.11) & $\begin{array}{c}4 \text { units: Leszno Plain (318.11.1), Gostyń Heights (318.11.2), Poniec Plain (318.11.3), Góra } \\
\text { Elevation (318.11.4) }\end{array}$ \\
\hline Kalisz Heights (318.12) & $\begin{array}{c}14 \text { units: Gostkowo Plain (318.12.1), Miejska Górka Plain (318.12.2), Krobia He- } \\
\text { ights (318.12.3), Koźmin Plain (318.12.4), Krotoszyn Ridge (318.12.5), Jarocin He- } \\
\text { ights (318.12.6), Krotoszyn Plateau (318.12.7), Pleszew Heights (318.12.8), Ostrów He- } \\
\text { ights (318.12.9), Kalisz Heights (318.12.10), Kalisz Hillocks (318.12.11), Ostrów Hillocks } \\
\text { (318.12.12), Jutrosin Basin (318.12.13), ŻerkówRydzyna Valley (318.12.14) }\end{array}$ \\
\hline Konin Valley (318.13) & 1 unit: Konin Valley (318.13.1) \\
\hline Koło Basin (318.14) & 2 units: Koło-Brudzew Basin (318.14.1), Lower Ner River Valley (318.14.2) \\
\hline Kłodawa Heights (318.15) & $\begin{array}{c}6 \text { units: Koło Elevation (318.15.1), Grzegorzew Plain (318.15.2), Orłówka River Val- } \\
\text { ley (318.15.3), Souther Kłodawa Heights (318.15.4), Northern Kłodawa Plain (318.15.5), } \\
\text { Krośniewice Heights (318.15.6) }\end{array}$ \\
\hline Rychwał Plain (318.16) & $\begin{array}{c}4 \text { units: Gizałki Basin (318.16.1), Chocz Plain (318.16.2), Rychwał-Konin Plain (318.16.3), } \\
\text { Dzierzbin Plain (318.16.4) }\end{array}$ \\
\hline Turek Heights (318.17) & $\begin{array}{c}4 \text { units: Koźmin Hillocks (318.17.1), Malanów Ridge (318.17.2), Złota Góra Hillocks } \\
\text { (318.17.3), Dobra Heights (318.17.4) }\end{array}$ \\
\hline
\end{tabular}


Table 2. Continued.

\begin{tabular}{|c|c|}
\hline Sieradz Basin (318.18) & Sieradz Basin (318.18.1) \\
\hline Grabów Basin (318.21) & (318.21.2) \\
\hline Złoczew Heights (318.22) & 1 unit: Western Złoczew Heights (318.22.1) \\
\hline Wieruszów Heights (318.24) & 2 units: Kępno Plain (318.24.1), Trzcinica Sandur (318.24.2) \\
\hline Żmigród Basin (318.33) & unit: Rawicz Basin (318.33.1) \\
\hline Milicz Basin (318.34) & 2 units: Southern Przygodzice Plain (318.34.1), Odolanów Basin (318.34.2) \\
\hline Twardogóra Hills (318.45) & 1 unit: Eastern Twarda Góra Hills (318.45.1) \\
\hline Ostrzeszów Hills (318.46) & 1 unit: Rychtal Plain (318.56.1) \\
\hline Oleśnica Plain (318.56) & (318.21.1 \\
\hline
\end{tabular}

Source: Own works (2019)

layout is enforced by greater variability of elements and environmental features and the presence of environmental units connected with subsidence (large river valleys). For this reason, the microregions described are characterized by smaller area and a higher degree of boundary development (Table 3). This is connected with the fact that the microregions are located within the zone of the last glaciation, so that the variability and contrasting nature of land relief as well as the related differences in height and declines are much bigger. The presence of numerous end moraines and lake troughs provides the most characteristic examples illustrating the morpho-genetic conditions.
The genetic characteristics of these areas is manifested in the variable geological structure and related diversity of soil conditions, water relations and occurring potential vegetation community types. That was decisive of the mosaic nature of land coverage and high physiognomic landscape assets. The best examples of the described situation are microregions located within the boundaries of mesoregions: the Gwda River Valley (314.68), Southern Krajna Lakeland (314.74), Poznań Lakeland (315.51), Chodzież Lakeland (315.53), Gniezno Lakeland (315.54), Kuyavian Lakeland (315.57), Żnin-Mogilno Lakeland (315.58) and Grodzisk Heights (315.59).

Table 3. Characteristics of selected mesoregions.

\begin{tabular}{|c|c|c|c|c|}
\hline Area & Number of microregions & Microregion & $\begin{array}{l}\text { Microregion area } \\
\text { [ha] }\end{array}$ & $\begin{array}{l}\text { Length of the microregion boundary } \\
\qquad[\mathrm{km}]\end{array}$ \\
\hline \multirow{3}{*}{$\begin{array}{l}\text { Wielkopolskie } \\
\text { voivodeship }\end{array}$} & \multirow{3}{*}{181} & Biggest & 68.797 .82 & 137.24 \\
\hline & & Medium & 16.478 .5 & 33.0 \\
\hline & & Smallest & 1.819 .18 & 24.03 \\
\hline \multicolumn{5}{|c|}{ Young glacial area } \\
\hline \multirow{3}{*}{$\begin{array}{l}\text { Gniezno Lakeland } \\
\qquad(315.54)\end{array}$} & \multirow{3}{*}{10} & Biggest & 30.659 .55 & 105.914 \\
\hline & & Medium & 16.159 .27 & 76.66 \\
\hline & & Smallest & 6.315 .76 & 42.903 \\
\hline \multirow{3}{*}{$\begin{array}{l}\text { Grodzisk Heights } \\
\quad(315.59)\end{array}$} & \multirow{3}{*}{7} & Biggest & 389.260 .51 & 130.907 \\
\hline & & Medium & 21.702 .19 & 79.58 \\
\hline & & Smallest & 10.718 .79 & 51.940 \\
\hline \multicolumn{5}{|c|}{ Peryglacial area } \\
\hline \multirow{3}{*}{ Rychwał Plain (318.16) } & \multirow{3}{*}{4} & Biggest & 43.837 .81 & 119.335 \\
\hline & & Medium & 28.977 .64 & 98.89 \\
\hline & & Smallest & 15.613 .54 & 86.470 \\
\hline \multirow{3}{*}{ Kalisz Heights (318.12) } & \multirow{3}{*}{14} & Biggest & 68.797 .82 & 137.237 \\
\hline & & Medium & 25.840 .28 & 91.12 \\
\hline & & Smallest & 8.239 .30 & 55.667 \\
\hline
\end{tabular}

Source: Own works (2019) 
Table 4. Scope of application of physical and geographic division of units in ecophysiographic analyses in Poland illustrated with examples of the various voivodeships.

\begin{tabular}{|c|c|c|c|c|c|c|c|}
\hline \multirow{2}{*}{$\begin{array}{c}\text { Selected issues } \\
\text { of ecophysiographic study }\end{array}$} & \multicolumn{5}{|c|}{ voivodeship } \\
\cline { 2 - 7 } & Dolnośląskie & $\begin{array}{c}\text { Kujawsko- } \\
\text { Pomorskie }\end{array}$ & Lódzkie & $\begin{array}{c}\text { Mazo- } \\
\text { wieckie }\end{array}$ & Opolskie & $\begin{array}{c}\text { Pomor- } \\
\text { skie }\end{array}$ & $\begin{array}{c}\text { Wielko- } \\
\text { polskie }\end{array}$ \\
\hline Area location characteristics & $\mathrm{X}$ & $\mathrm{X}$ & $\mathrm{X}$ & $\mathrm{X}$ & $\mathrm{X}$ & - & $\mathrm{X}$ \\
\hline Environment structure and functioning & $\mathrm{X}$ & $\mathrm{X}$ & $\mathrm{X}$ & $\mathrm{X}$ & $\mathrm{X}$ & $\mathrm{X}$ & $\mathrm{X}$ \\
\hline $\begin{array}{c}\text { Risk analysis and environmental resistance } \\
\text { to risk analysis }\end{array}$ & 0 & - & 0 & $\mathrm{X}$ & $\mathrm{X}$ & $\mathrm{X}$ & 0 \\
\hline $\begin{array}{c}\text { Assessment of the environment capacity for the } \\
\text { performance of ecological and socio-economic } \\
\text { functions }\end{array}$ & $\mathrm{X}$ & 0 & $\mathrm{X}$ & $\mathrm{X}$ & $\mathrm{X}$ & 0 & $\mathrm{X}$ \\
\hline $\begin{array}{c}\text { Assessment of compliance of the current } \\
\text { management with environmental conditions }\end{array}$ & $\mathrm{X}$ & - & 0 & $\mathrm{X}$ & 0 & 0 & - \\
\hline $\begin{array}{c}\text { Preliminary forecast of changes } \\
\text { in the environment }\end{array}$ & 0 & 0 & 0 & 0 & 0 & $\mathrm{X}$ & - \\
\hline $\begin{array}{c}\text { Proposed directions of development and eco- } \\
\text { physiographic recommendations }\end{array}$ & $\mathrm{X}$ & 0 & $\mathrm{X}$ & $\mathrm{X}$ & 0 & 0 & $\mathrm{X}$ \\
\hline \begin{tabular}{c} 
Actual and potential functional collisions \\
\hline
\end{tabular} & 0 & 0 & - & $\mathrm{X}$ & 0 & 0 & 0 \\
\hline
\end{tabular}

Source: own study based on ecophysiographic studies of selected provinces

Legend: $\mathrm{X}$ - issue analysed with the application of physiographic units, 0 - issue analysed independently of the physiographic division units - the issue omitted in the analysis.

In the southern and western parts of the voivodeship, microregions with bigger area and more regular and compact shapes are dominant (Table 3). This is usually caused by their location in the periglacial Odra River glaciation. The homogeneous nature of these units results from the prevalence of flat or wavy upland areas with minor height differences, which are dismembered by river valleys and the lack of natural subsidence in the form of lakes (see Appendices, Table 2). This is manifested mainly by the presence of denudational moraine plains diversified by episodic inselberg glacial forms. The genesis of these units exerted an impact not only on physiognomic landscape assets but also on the existing habitat conditions connected with the features of subsurface geological structure, soils and groundwaters. This contributed to a noticeable prevalence of mixed forests or hornbeam-oak forest habitats and intensive use of these areas for agricultural economy. The examples of microregions representing the conditions described include the ones located within the boundaries of the Kalisz Heights (318.12), Rychwał Plain (318.16), and Turek Heights (318.17).

A number of methodological problems were encountered during the research proceedings. The first one was the necessity to adjust the division of the province (voivodeship) into physical and geographic microregions to the physical and geographic regionalization that is applied in Poland [29]. The aforementioned study considers the division of the country into regional units in a hierarchical layout, taking into consideration four levels of divisions: provinces, sub-provinces, macroregions and mesoregions. In effect, in some cases it proved necessary to verify the originally obtained boundaries of microregions so that they were tangential to the higher-level unit boundaries. The difference in the course of microregion boundaries in comparison to mesoregion boundaries was $35 \%$ and it resulted from the applied delimitation method and higher accuracy of source materials. For the purposes of the study, the method of boundary analysis using thematic divisions was based on a wide range of criteria, including geological structure, relief, waters, soils and vegetation cover. The aim of the methodological solution adopted in the study was to fulfil the formal conditions, i.e., the comprehensive nature of physical and geographic regionalization in the case of the microregion range units and, subsequently, to enhance the cognitive and application meaning of the results obtained. On the other hand, the physical and geographic division of Poland was carried out with the leading factor method, where the major criteria included the features of geological structure and land relief [22, 29]. For comparison, geological structure, land relief and land coverage was approached with greater accuracy and became the basic criteria of microregion divisions in the study relating to Kujawsko-Pomorskie Voivodeship [30].

Moreover, the quality of source materials applied also influenced the research results. Different geometric accuracy of thematic data and different level of detail of divisions characterizing particular elements and environmental features were decisive for the precision of the boundaries obtained and the final number of microregions and the size thereof 
[27-28]. Although most thematic data corresponds to the level of detail appropriate for the scale of 1:50,000, explicit discontinuity of some boundaries was noticeable, which required the application of an expert approach. This consisted of repeated analysis of the importance of particular thematic divisions, starting with the general ones (e.g., types of vegetation communities) to the most detailed ones (e.g., downslope). In effect, this enabled the elaboration of the final vector layer at which all the lines obtained are tangential to one another and they keep continuity by the boundaries.

\section{Conclusions}

Regional divisions are considered to be of substantial cognitive importance, which is expressed in the form of cohesive and systematized environmental characteristics and the characteristics of its spatial diversification. The proposed physical and geographic regionalization of the Wielkopolskie Voivodeship meets the defined formal requirements that apply to the delimitation of regional units at the microregion level and it is based on a comprehensive analysis of environmental conditions [22]. The source materials used in the project as well as the microregion characteristics prepared on the basis thereof enable ecological indexation of particular units. This poses a chance for the use of areas delimited in this way as operational units for which physical and geographic information is gathered, processed and rendered available for various problem analyses carried out $[23,31]$

The conditions described above have an impact on extensive possibilities of practical application of the presented regionalization. The changes of legal conditions as regards environmental management, occurring at the end of the $20^{\text {th }}$ century and continued in the $21^{\text {st }}$ century, favor that. They focus on the increasing role of landscape research and landscape classification in assuring effective protection of environmental assets and reasonable use thereof. This refers in particular to strategic documents connected with spatial and economic planning performed at the scale of the country and the province as well as smaller functional areas. The provisions of the act of 27 April 2001 - Environmental Protection Law and the act of 27 March 2003 on spatial planning and management implement the obligation to perform indepth environmental analyses for the purposes of planning documents. They are most often presented in the form of ecophysiographic studies, whose scope of issues assumes common use of spatial references (regionalization or physical and geographic typology units) allowing for making diversified evaluations valuing the environment (Table 4). As the designated microregions are relatively homogeneous units from the point of view of environmental features and their genesis, it should be considered that they meet formal requirements set for ecophysiographic analyses at the level of provinces to a sufficient extent.

The act of 2015 amending certain acts in relation to strengthening landscape protection instruments in Poland and the regulation of the Council of Ministers on preparation of landscape audits assumes the leading role of physical and geographic division units in the designation of so-called priority landscapes. Priority landscape identification at the scale of the voivodeship will be implemented within the area of physical and geographic mesoregions, within the boundaries of which lower range landscapes (i.e., physical and geographic microregions) may be designated. Physical and geographic mesoregions, and in justified cases microregions, as basic units enabling further analysis and classification of landscapes within the framework of groups, types and subtypes. Microregions may prove especially helpful in cases where large mesoregions exist, which are additionally dominated by a single type of landscape. In Wielkopolskie this applies to valleys of large rivers (i.e., the Warta and Noteć) and large highland areas in various parts of the voivodeship. Such a situation may result in lower values of specific landscape indicators in comparison to other units, and it may hinder the determination of priority landscapes.

The application of the elaborated physical and geographic microregionalization of the Wielkopolskie voivodeship to the landscape audit is supported by the fact of its adjustment to the division into physical and geographic mesoregions [29]. The described approach guarantees universalism and long-term validity of analyses performed on the basis thereof. As the landscape audit is a study prepared at least once every 20 years, the adoption of such a solution seems particularly substantiated.

\section{Conflict of Interest}

The authors declare no conflict of interest.

\section{References}

1. DE MONTIS A. Impacts of the European Landscape Convention on national planning systems: a comparative investigation of six case studies. Landscape and Urban Planning. 124, 53, 2014.

2. BUTLER A., BERGLUND U. Landscape Character Assessment as an Approach to Undersatnding Public Interests within the European Landscape Convention. Landscape Research. 39 (3), 219, 2014.

3. MIKUSIŃSKI G., BLICHARSKA M., ANTONSON H., HENNINGSSON M., GÖRANSSON G., ANGELSTAM P., SEILER A. Integrating ecological, social and cultural dimensionsin the implementation of the Landscape Convention. Landscape Research. 38, 384, 2014.

4. NITĂ A., BUTTLER A., ROZYLOWICZ L., PĂTRUSTUPARIU I.L., PĂTRU-STUPARIU I. Perception and use of landscape concepts in the procedure of 
Environmenral Impact Assessment: Case study Switzerland and Romania. Land Use Policy. 44, 145, 2015.

5. PAIGE FISHER A., KLOOSTER A., CIRHIGIRI L. Cross-boundry cooperation for landscape management: Collective action and social exchange among individual private forest landowners. Landscape and Urban Planning 188, 151, 2019.

6. KUBACKA M., MACIAS A. The functioning of Natura 2000 areas in the opinion of different groups from the local community. A Case Study from Poland. Society\&Natural Resources. 29, 1186, 2016.

7. PECHANEC V., BRUS J., KILIANOVÁ H., MACHAR I. Decision support tool for the evaluation of landscapes. Ecological Informatics 30, 305, 2015.

8. HAZEU G.W., METZGER M.J., MÜCHER C.A., PEREZ-SOBA M., RENETSEDER C., ANDERSEN E. European environment al stratifications and typologies: An overview. Agriculture, Ecosystems\&Environment. 142 (1-2), 29, 2011.

9. KOLEJKA J., LIPSKŶY Z. Landscape mapping and typology in the Czech Republic. Problemy Ekologii Krajobrazu. 20, 5, 2014.

10. SIMENSEN T., HULVORSEN R., ERIKSTAD L. Methods for landscape characterisation and mapping: A systematic review. Land Use Policy. 75, 557, 2018.

11. CHORLEY R.J., HAGGETT P. Models in geography. London: Methuen. 1967.

12. LI G., ZHANG B. Identification of landscape character types for trans-regional integration In the Wuling Mountain Multi-ethnic area of southwest China. Landscape and Urban Planning. 162, 25, 2017.

13. CHAI H., ZHOU C., CHEN C.X., WEIMING C. Digital regionalization of geomorphology in Xinjiang. Journal of Geographical Sciences. 19, 600, 2009.

14. PETERSON H.M., NIEBER J.L., KANIVETSKY R. Hydrologic regionalization to assess anthropogenic changes. Journal of Hydrology. 408, 212, 2011.

15. KREFT H., JETZ W. A framework for delineating biogeographical regions based on species distributions. Journal of Biogeography. 37, 2029, 2010.

16. HARGROVE W.W., HOFFMAN F.M. Potential of multivariate quantitative methods for delineation and visualization of ecoregions. Environmental Management. 34, 39, 2004.

17. SOLECKA I., RASZKA B., KRAJEWSKI P. Landscape analysis for sustainable land use policy: A case study in the municipality of Popielów, Poland. Land Use Policy. 75, 116,2018

18. MENG Q. Regional landscape mapping through a method of chain standardization of Landsat images. Landscape and Urban Planning. 134, 1, 2015.
19. KUBACKA M. Evaluation of the ecological efficiency of landscape protection in areas of different protection status. A case study from Poland. Landscape Research 44, 628, 2019.

20. KONDRACKI J. Types of natural landscape in Poland. Polish Geographical Review. 32, 1, 1960.

21. KONDRACKI J. Regional geography of Poland. PWN. Warsaw. 2000 [In Polish].

22. KONDRACKI J. Regional geography of Poland. PWN. Warsaw. 2000 [In Polish].

23. BRÓDKA S. Landscape classifications in Poland methodological assumptions and applications. [In:] Qualitative research in regional studies. D. KonieczkaŚliwińska i I. Miedzińska (ed.). Publication of the Institute of History. 133, 121, 2016 [In Polish].

24. OSTASZEWSKA K. Landscape geography. PWN. Warsaw. 2002 [In Polish].

25. KRAJEWSKI P. Assessing change in high-value landscape: Case study of the Municipality of Sobotka, Poland. Pol. J. Environ. Stud. 26, 6, 2017.

26. KRAJEWSKI P. Role of landscape audit in the context of functioning principles of selected protected areas. Problems of Landscape Ecology. 43, 63, 2016.

27. SOLON J., CHMIELEWSKI T.J., MYGA-PIĄTEK U., KISTOWSKI M. Preparation of the study „Identification and assessment of landscape - methodology and main assumptions. Polish Academy of Sciences. 2014 [In Polish].

28. MYGA-PIĄTEK U., NITA J., SOBALA M., PUKOWIEC K., DZIKOWSKA P., ŻEMŁA-SIESICKA A., PIĄTEK J. Preparation of landscape audit - testing the methodology of landscape identification and assessment. Consulting. 2015 [In Polish].

29. SOLON J., BORZYKOWSKI J., BIDŁASIK M., RICHLING A., BADORA K., BALON J., BRZEZIŃSKAWÓJCIK T., CHABUDZIŃSKI Ł., DOBROWOLSKI R., GRZEGORCZYK I., JODŁOWSKI M., KISTOWSKI M., KOT R., KRĄŻ P., LECHNIO J., MACIAS A., MAJCHROWSKA A., MALINOWSKA E., MIGOŃ P., MYGA-PIĄTEK U., NITA J., PAPIŃSKA E., RODZIK J., STRZYŻ M., TERPIŁOWSKI S., ZIAJA W. PhysicoGeographical Mesoregions of Poland: Verification and Adjustment of Boundaries on the Basis of Contemporary Spatial Data. Geographia Polonica. 91, 143, 2018.

30. KOT R. Methodology of physico-geographical classification of the Kuyavian-Pomeranian Voivodeship). The Problems of Landscape Ecology. XLI, 43, 2016 [In Polish].

31. MACIAS A., BRÓDKA S. Nature (abiotic and biotic) features and objects - distinguishing features of landscape identity. The Problems of Landscape Ecology. 40, 187, 2015 [In Polish]. 